\title{
Influence of Silica Nano-Additives on Performance and Emission Characteristics of Soybean Biodiesel Fuelled Diesel Engine
}

\author{
R. S. Gavhane ${ }^{1, *}$, A. M. Kate ${ }^{2}$, Manzoore Elahi M. Soudagar ${ }^{3}$ D, V. D. Wakchaure ${ }^{1}$, Sagar Balgude ${ }^{4}$, \\ I. M. Rizwanul Fattah ${ }^{5, *(D)}$, Nik-Nazri Nik-Ghazali ${ }^{3} \mathbb{D}$, H. Fayaz ${ }^{6} \mathbb{D}$, T. M. Yunus Khan $^{7} \mathbb{D}$, M. A. Mujtaba $^{3} \mathbb{D}$, \\ Ravinder Kumar ${ }^{8}$ and M. Shahabuddin $9, *$ (D)
}

check for updates

Citation: Gavhane, R.S.; Kate, A.M.; Soudagar, M.E.M.; Wakchaure, V.D.; Balgude, S.; Rizwanul Fattah, I.M.; Nik-Ghazali, N.-N.; Fayaz, H.; Khan, T.M.Y.; Mujtaba, M.A.; et al. Influence of Silica Nano-Additives on

Performance and Emission

Characteristics of Soybean Biodiesel Fuelled Diesel Engine. Energies 2021, 14, 1489. https://doi.org/10.3390/ en14051489

Academic Editor: João Fernando Pereira Gomes

Received: 2 February 2021

Accepted: 1 March 2021

Published: 9 March 2021

Publisher's Note: MDPI stays neutral with regard to jurisdictional claims in published maps and institutional affiliations.

Copyright: (c) 2021 by the authors. Licensee MDPI, Basel, Switzerland. This article is an open access article distributed under the terms and conditions of the Creative Commons Attribution (CC BY) license (https:/ / creativecommons.org/licenses/by/ $4.0 /)$.
1 Department of Mechanical Engineering, Amrutvahini College of Engineering, Sangamner, Ahmednagar 422608, India; wvishnu@gmail.com

2 Department of Mechanical Engineering, Zeal College of Engineering and Research, Pune 411041, India; ajit.kate@zealeducation.com

3 Department of Mechanical Engineering, Faculty of Engineering, University of Malaya, Kuala Lumpur 50603, Malaysia; me.soudagar@gmail.com (M.E.M.S.); nik_nazri@um.edu.my (N.-N.N.-G.); m.mujtaba@uet.edu.pk (M.A.M.)

4 D Y Patil College of Engineering, Savitribai Phule Pune University, Maharashtra 411044, India; sagarbalgude88@gmail.com

5 School of Information, Systems and Modelling, Faculty of Engineering and I.T., University of Technology Sydney, Ultimo, NSW 2007, Australia

6 Modeling Evolutionary Algorithms Simulation and Artificial Intelligence, Faculty of Electrical \& Electronics Engineering, Ton Duc Thang University, Ho Chi Minh City, Vietnam; fayaz@tdtu.edu.vn

7 Mechanical Engineering Department, College of Engineering, King Khalid University, PO Box 394, Abha 61421, Saudi Arabia; yunus.tatagar@gmail.com

8 Department of Mechanical Engineering, Lovely Professional University, Kapurthala, Punjab 144411, India; rav.chauhan@yahoo.co.in

9 Carbon Technology Research Centre, School of Engineering, Information Technology and Physical Sciences, Federation University Australia, Churchill, VIC 3842, Australia

* Correspondence: rakhmaji.gavhane@avcoe.org (R.S.G.); IslamMdRizwanul.Fattah@uts.edu.au (I.M.R.F.); s.ahmmad@federation.edu.au (M.S.)

Abstract: The present study examines the effect of silicon dioxide $\left(\mathrm{SiO}_{2}\right)$ nano-additives on the performance and emission characteristics of a diesel engine fuelled with soybean biodiesel. Soybean biofuel was prepared using the transesterification process. The morphology of nano-additives was studied using scanning electron microscopy (SEM), X-ray diffraction (XRD) and energy-dispersive X-ray spectroscopy (EDS). The Ultrasonication process was used for the homogeneous blending of nano-additives with biodiesel, while surfactant was used for the stabilisation of nano-additives. The physicochemical properties of pure and blended fuel samples were measured as per ASTM standards. The performance and emissions characteristics of different fuel samples were measured at different loading conditions. It was found that the brake thermal efficiency (BTE) and brake specific fuel consumption (BSFC) increased by $3.48-6.39 \%$ and $5.81-9.88 \%$, respectively, with the addition of $\mathrm{SiO}_{2}$ nano-additives. The carbon monoxide $(\mathrm{CO})$, hydrocarbon $(\mathrm{HC})$ and smoke emissions for nano-additive added blends were decreased by $1.9-17.5 \%, 20.56-27.5 \%$ and $10.16-23.54 \%$ compared to SBME25 fuel blends.

Keywords: soybean biodiesel; engine performance; engine emission; nano-additives; SEM

\section{Introduction}

The current scenario of increasing fuel prices and depletion of fossil fuels has increased demand for renewable energy in the industry and heavy-duty diesel engines [1-3]. Biodiesel is one of the potential sources of clean and green energy for today's world's 
sustainable development [4]. Biodiesel is a clean-burning fuel that helps to decrease the emission of unburnt hydrocarbon (HC), carbon monoxide (CO) and smoke emissions [5-7]. On the contrary, due to lower heating value than petroleum-based fuels, lower brake power (BP) and higher brake specific fuel consumption (BSFC) is observed [8]. Biodiesel is also reported to increase nitrogen oxides (NOx) emissions $[9,10]$. It was found that soybean biodiesel has properties similar to diesel fuel and different blends of soybean biodiesel can be used in a diesel engine without significant alteration [11,12]. However, some adverse effects are observed associated with biodiesel use. For example, Özener et al. [13] reported that the blends of soybean biodiesel showed a 1-4\% decrease in the brake torque and a $2-9 \%$ increase in BSFC. They attributed the reduction in the BSFC and torque results to the $12 \%$ lower energy content of the biodiesel compared to that of conventional diesel fuel. They also reported a $6.95-17.62 \%$ increase in NOx emission. They pointed out that one possible explanation could be the oxygen content of biodiesel which cause a complete combustion reaction when using the biodiesel, resulting in a higher combustion temperature that triggers $\mathrm{NO}_{x}$ formation. Another recent study by Seraç et al. [14] studied the performance, combustion and exhaust emission characteristics of $5 \%$ and $20 \%$ by volume soybean biodiesel blend with ultra-low sulphur diesel (ULSD). Tests were carried out at constant power output. They reported a maximum increase in BSFC of $8 \%$ for $20 \%$ biodiesel blend compared to that of ULSD. They also reported the lowest HC emission and highest NOx emission for $20 \%$ biodiesel blend compared to ULSD. They attributed these changes to the higher cetane number and lower heating value of biodiesel. A higher cetane number would result in faster ignition. With a shorter ignition time, the onset of combustion is earlier than that of diesel fuel resulting in the above-mentioned changes.

Novel method was employed by blending the biodiesel with nano-sized particles to overcome the limitations of biodiesel [15]. The nano additives in biodiesel act as a combustion catalyst. These particles enhance the combustion phenomenon; thus, complete combustion takes place due to the increase in net heat generated inside the combustion chamber that enhances the BTE with a reduction in BSFC. Furthermore, the addition of these nanoparticles reduces the emissions like $\mathrm{CO}_{2}, \mathrm{HC}$ and smoke except NOx. The NOx increases with the increase in combustion chamber temperature. The addition of fuel additives to improve fuel properties, thereby the combustion characteristics, have become a recent trend in research due to obvious benefits [16-19]. It has been reported that nano-additives effectively reduce the agglomeration during blending with fuel and improve engine characteristics due to the large surface air-to-volume ratio, favourable thermophysical properties and high thermal conductivity $[20,21]$. The combined effect of these properties assists in decreasing BSFC as well as engine emissions $[17,19,22]$. A previous review by Soudagar et al. [1] pointed out an extensive literature gap in the investigations to the addition of various types of nano-additives in various biodiesel feedstocks. Najafi [21] studied the combustion characteristics of carbon nanotubes (CNT) and Ag nano-additives treated diesel-biodiesel blend. The author showed that the addition of nano-additives to diesel-biodiesel blends resulted in an increase in the in-cylinder peak pressure and the peak pressure rise rate compared to that of neat diesel fuel. Ghanbari et al. [23] attributed this to the shorter ignition delay resulting in earlier and higher maximum cylinder pressure. An earlier study by the same group studied the performance and emission characteristics of nano-additive added blends. They showed that these blends reduced BSFC by $7.08 \%$, CO emissions decreased by $25.17 \%$ and NOx emissions increased by $25 \%$ to $32 \%$ on average compared to diesel fuel. Research on enhancing the performance and emission characteristics using silica nano-additives to biodiesel is still minimal.

Adzmi et al. [24] studied the effect of adding silica $\left(\mathrm{SiO}_{2}\right)$ nano-additives (50 and $100 \mathrm{ppm}$ ) to palm biodiesel blend on the performance and emission of a diesel engine. Tests were carried out in a single-cylinder diesel engine at various operating load and constant engine speed condition. They reported an increased BP, reduced CO and NOx emission with the addition of silica nano-additives. They reported a $43 \%$ increase in $\mathrm{BP}$, a $25 \%$ reduction in $\mathrm{CO}$ emissions and a $4.48 \%$ reduction in NOx emission at various 
load conditions and amount of silica nano-additives. Saravankumar et al. [25] used silica nano-additives as an additive (at 50, 75 and $100 \mathrm{ppm}$ ) to the $20 \%$ corn oil methyl ester blends with diesel in the form of emulsions. Test results showed that the addition of nano-additives was conducive to decreasing the $\mathrm{HC}$ emission due to promoting complete combustion via acting as an oxygen buffer that supplies enough oxygen at higher loads. They also reported lower smoke emission for nano-additives blended fuels as the presence of nano-additives leads to better evaporation rate and enhanced oxidation property of the fuel, which facilitates complete combustion of the fuel. However, they reported an increase in NOx emission due to addition of silica nano-additives, which they attributed to the higher oxygen content in fuel as well as the temperature inside the combustion chamber.

Özgür et al. [26] studied the effect of $\mathrm{SiO}_{2}$ nano-additives addition at the dosage of 25 and $50 \mathrm{ppm}$ in rapeseed methyl ester on diesel engine performance and emission. They reported a maximum increase of $4.2-4.8 \%$ of BP and 3.6-4.3\% of brake torque for 25 and 50 ppm blends, respectively. A maximum average CO reduction of $10.4 \%$ was obtained for a $25 \mathrm{ppm}$ silica nano-additives blend. The maximum NOx emission reduction of $7.2 \%$ and $9.4 \%$ were observed for 25 and $50 \mathrm{ppm}$ nanoparticle blends, respectively. Thus, it can be seen that the variation in the effect on diesel engine performance and emission depend on many factors and are generally not conclusive. Gavhane et al. [20] studied the effect of ZnO NPs and soybean biodiesel on engine characteristics. The authors observed an enhancement in the BTE, HRR and MGT by $23.2 \%, 19.45 \%$ and $2.4 \%$, while the CO, HC, $\mathrm{CO}_{2}$ and smoke emissions lowered by $28.21 \%, 32.23 \%, 21.66 \%$ and $22.5 \%$ and ID reduced by $26.2 \%$, while the NOx slightly increased. Figure 1 illustrates the comprehensive steps involved in the production of nano fuel blends.

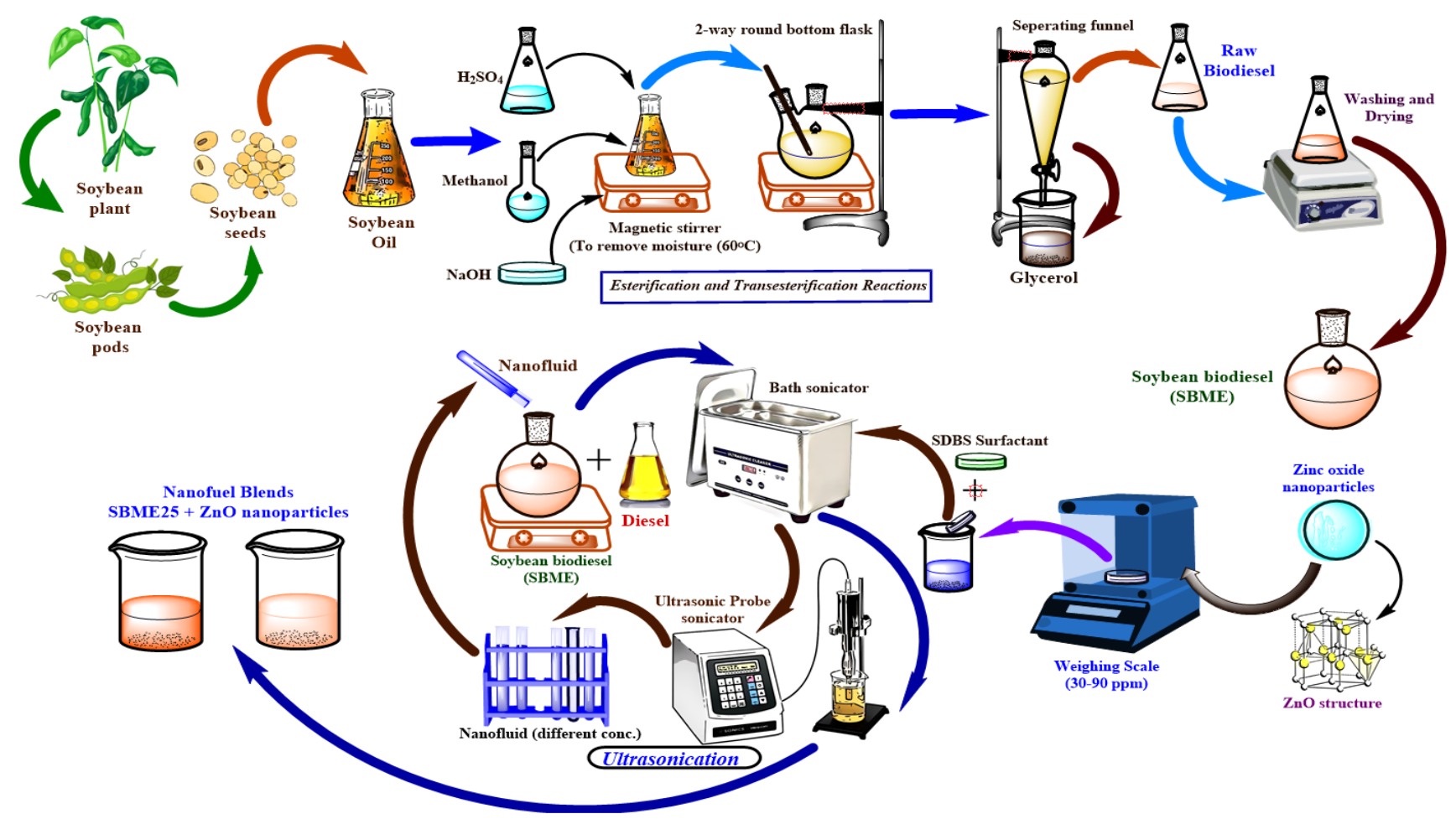

Figure 1. Comprehensive steps involved in the production of nano fuel blends [20].

The aim of the present investigation is to study the effect of NP additives and biodiesel fuel blends at varying loads in VCR diesel engine. The study delivers the potential of $\mathrm{SiO}_{2}$ NPs and SBME25 blend. SBME25 is blended with $\mathrm{SiO}_{2}$ NPs at different blending ratios $(25,50$ and $75 \mathrm{ppm})$. This study provides a direction to the further investigational facet of nano-additives in diesel-biodiesel fuel in CI engine application. 


\section{Materials and Methodology}

\subsection{Materials}

In this study, soybean seeds were collected from the local market and oil is extracted. The extracted oil was further used to produce biodiesel using the transesterification process. The $\mathrm{SiO}_{2}$ nano-additives (spherical, amorphous) was used in the current study. The size, molecular weight, surface area and density of the nano-additives were 5-20 nm, 60.08 and $590-690 \mathrm{~m}^{2} / \mathrm{g}$ and $2.2-2.6 \mathrm{~g} / \mathrm{mL}$ at $25^{\circ} \mathrm{C}$, respectively.

\subsection{Preparation of Soybean Biodiesel by Transesterification Process}

Drying of grains was carried out first to ensure good quality of oil during the oil extraction method. After that, pre-treatment on beans such as dehulling and grinding was carried out. A mechanical press with an electrical heater was employed for oil extraction. After extracting the raw soybean oil transesterification process was employed to produce biodiesel. In this process, crude soybean oil was reacted with methanol $(17 \% v / v$ oil) and $1 \%(w / w$ oil $)$ sodium methoxide and maintained at $60^{\circ} \mathrm{C}$ for two hours. The stirring of the mixture was carried out at $1000 \mathrm{rpm}$ to achieve a greater reaction. The produced biodiesel was poured into a separation funnel for $12 \mathrm{~h}$ to separate the glycerin from the biodiesel. Then, the lower layer, which contained impurities and glycerin, was drawn off after the completion of settling down. The produced methyl ester was washed with distilled water to remove the impurities and glycerin. In this process, $50 \%(v / v)$ distilled water at $60{ }^{\circ} \mathrm{C}$ was sprayed over the esters and shaken gently and the lower layer containing water and impurities was taken out. Then, methyl ester was subjected to vacuum distillation at $65^{\circ} \mathrm{C}$ for one hour using a rotary evaporator to remove excess water and remaining methanol. The whole process is shown in Figure 2, which illustrates (a) the steps involved in the production of soybean biodiesel oil from beans and (b) a schematic representation of the transesterification reaction.

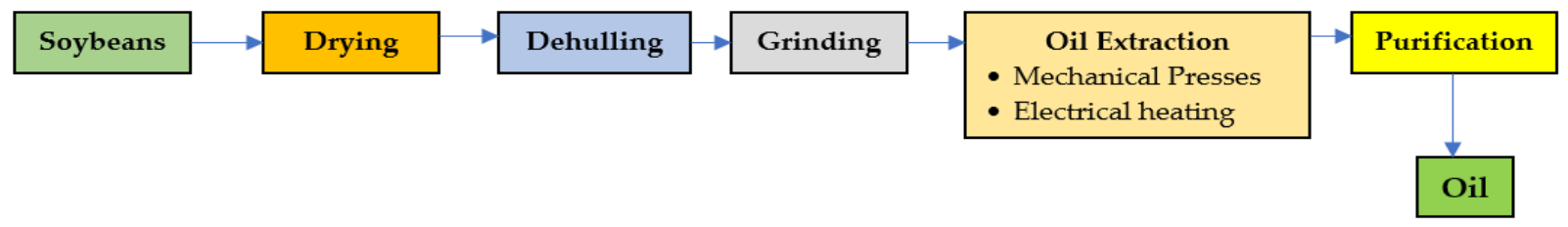

(a)

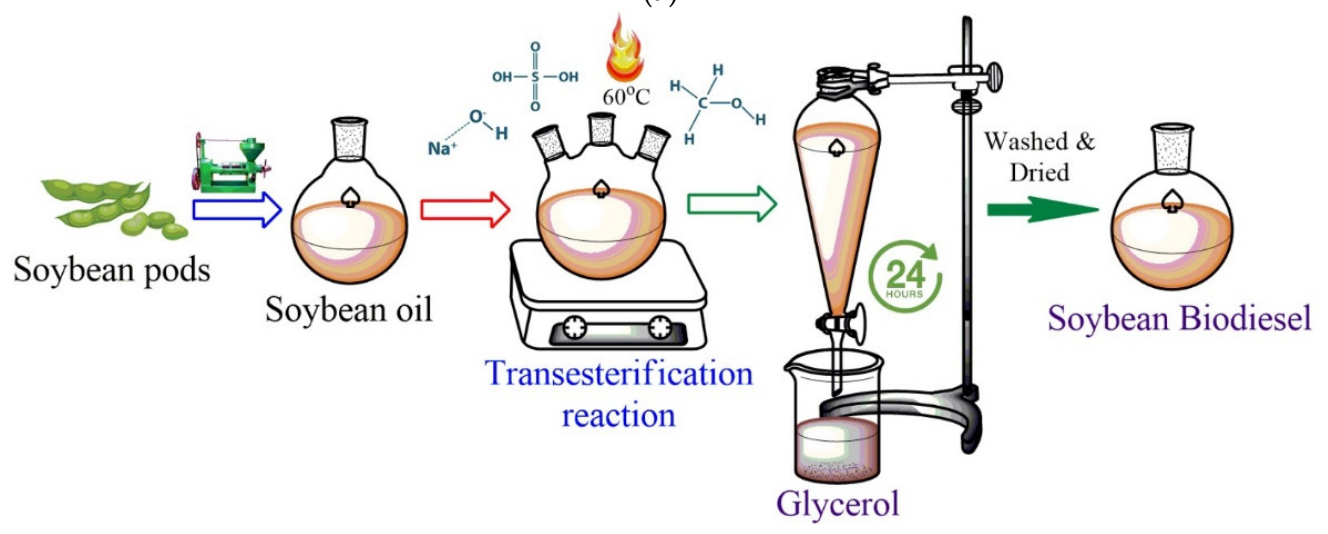

(b)

Figure 2. (a) Steps involved in the production of soybean oil from beans; (b) schematic representation of the transesterification reaction $[11,27]$.

\subsection{Characterisation of Silica Nano-Additive}

The morphology of $\mathrm{SiO}_{2}$ nano-additives was analysed using X-ray diffraction (XRD) shown in Figure 3. The XRD analysis was performed to analyse the crystalline structure of nano-additives using Xpert MPD, Philips, Holland XRD analyser, with a range of copper X-ray tubes from $5^{\circ}$ to $100^{\circ}$. The XRD structure reveals a broad, amorphous 
peak corresponding to Bragg angle at $2 \theta=22^{\circ}$ due to the amorphous phase of $\mathrm{SiO}_{2}$ in nano-additive. The minute size and partial internal structure of the nano-additive trigger this broad XRD peak. The result indicates that a high proportion of certain particles are amorphous [28]. This also illustrates the presence of $\mathrm{SiO}_{2}$ nano-additives with no other significant impurities. The results are consistent with the International Centre for Diffraction Data (JCPDS) $[29,30]$. Figure 4 illustrates the EDS analysis of the $\mathrm{SiO}_{2}$ nanoadditive. The EDS, also known as energy dispersive $\mathrm{X}$-ray analysis, was performed to determine the elemental and chemical analysis of the $\mathrm{SiO}_{2}$ nano-additives. The EDS analysis showed a higher quantity of silicon $(65.68 \%)$ with an adequate amount of oxygen molecules (30.4). In addition, some impurities were observed due to the previous stains of carbon and sodium in the canister [31]. The SEM analysis was carried out using XL 30 ESEM, EDAX Inc, USA, with an accelerating voltage of $200 \mathrm{kV}$ with the secondary and back detectors of the scattered electron. The $\mathrm{SEM}$ of $\mathrm{SiO}_{2}$ nano-additives at $6000 \times$ magnification is shown in Figure 5a,b.

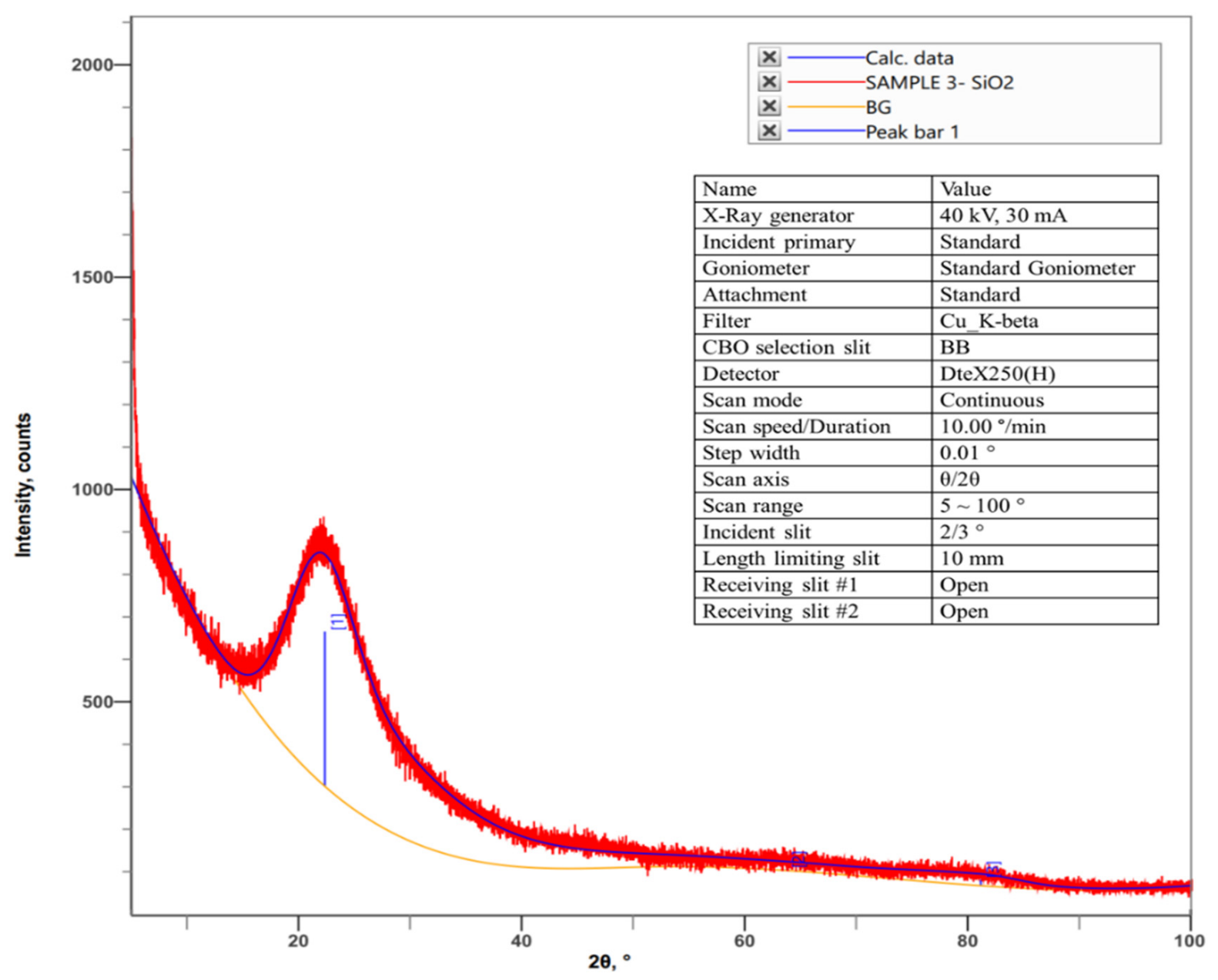

Figure 3. Crystalline structure of nano-additives, including measurement conditions. 


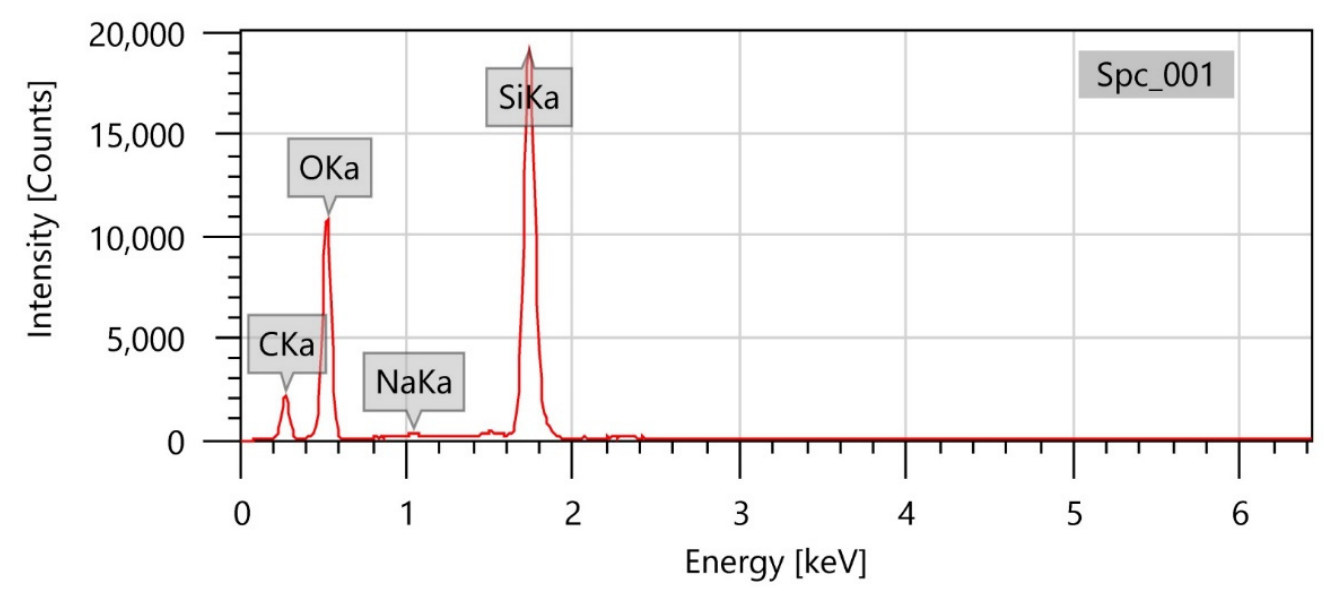

Figure 4. Elemental composition of $\mathrm{SiO}_{2}$ nano-additives.

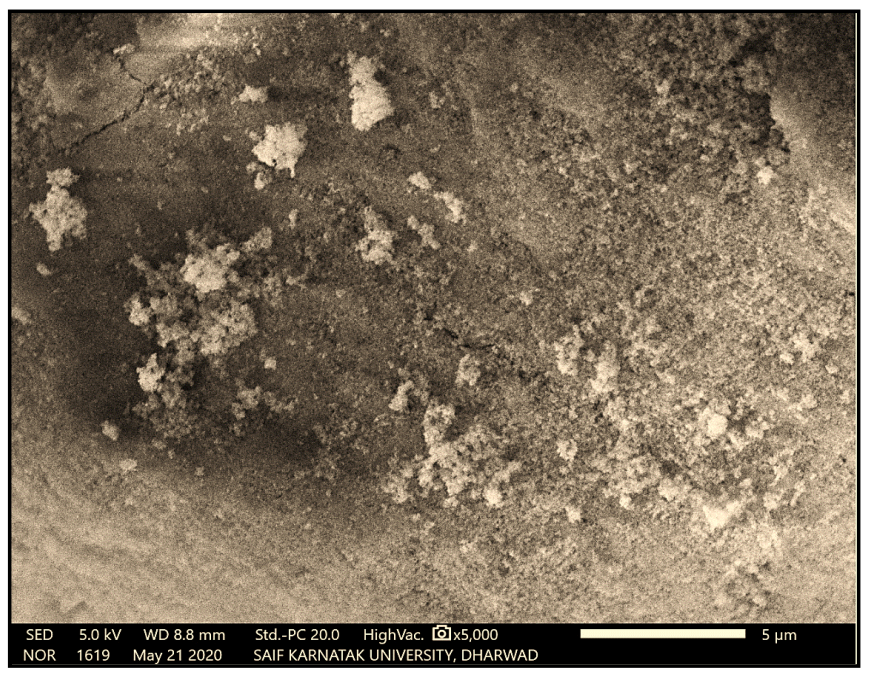

(a)

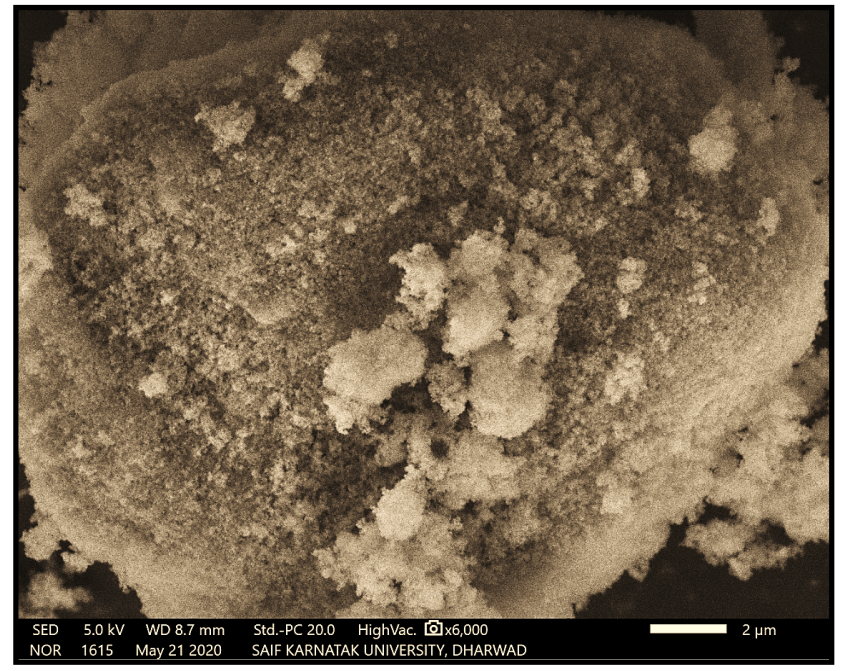

(b)

Figure 5. SEM analysis: (a) $5000 \times$ and (b) $6000 \times$ magnification.

\subsection{Preparation and Physicochemical Properties of Nano Fuel Blends}

In the current study, an ultrasonicator was used for making a well-mixed nano solution. To stabilise the blend, sodium dodecyl sulphate (SDS) surfactant was used for the ultrasonication process. The process was adapted from previous investigations by Soudagar et al. [2,3]. Initially, $25 \%$ of soybean biodiesel was blended with $75 \%$ diesel using an ultrasonication bath for $60 \mathrm{~min}$. An ultrasonication probe at $15-30 \mathrm{~Hz}$ was used for $20 \mathrm{~min}$ to mix the blend further. After that, $\mathrm{SiO}_{2}$ nano-additives along with SDS surfactant were transferred to the biodiesel blend and steadily mixed using a magnetic stirrer at $60^{\circ} \mathrm{C}$ for $30 \mathrm{~min}$ to remove traces of water molecules. Then, the same ultrasonication processes were carried out for a steady dispersion of $\mathrm{SiO}_{2}$ nano-additives in SBME25 biodiesel-diesel fuel blend. In the SBME25 blend, 25, 50 and $75 \mathrm{ppm}$ of $\mathrm{SiO}_{2}$ nano additive was added using an ultrasonicator. This process was adopted in the previous literature [20]. Figure 6 illustrates the schematic of the ultrasonication unit for the preparation of nano fuel. The physicochemical properties of fuel blends are shown in Table 1. As shown in Table 1, the addition of biodiesel resulted in increased density and reduced heating value. The addition of $\mathrm{SiO}_{2}$ nano-additive resulted in a reduction in density due to the high surface volume of nanoparticles and a small increase in heating value owing to the heating value of $\mathrm{SiO}_{2}$. 


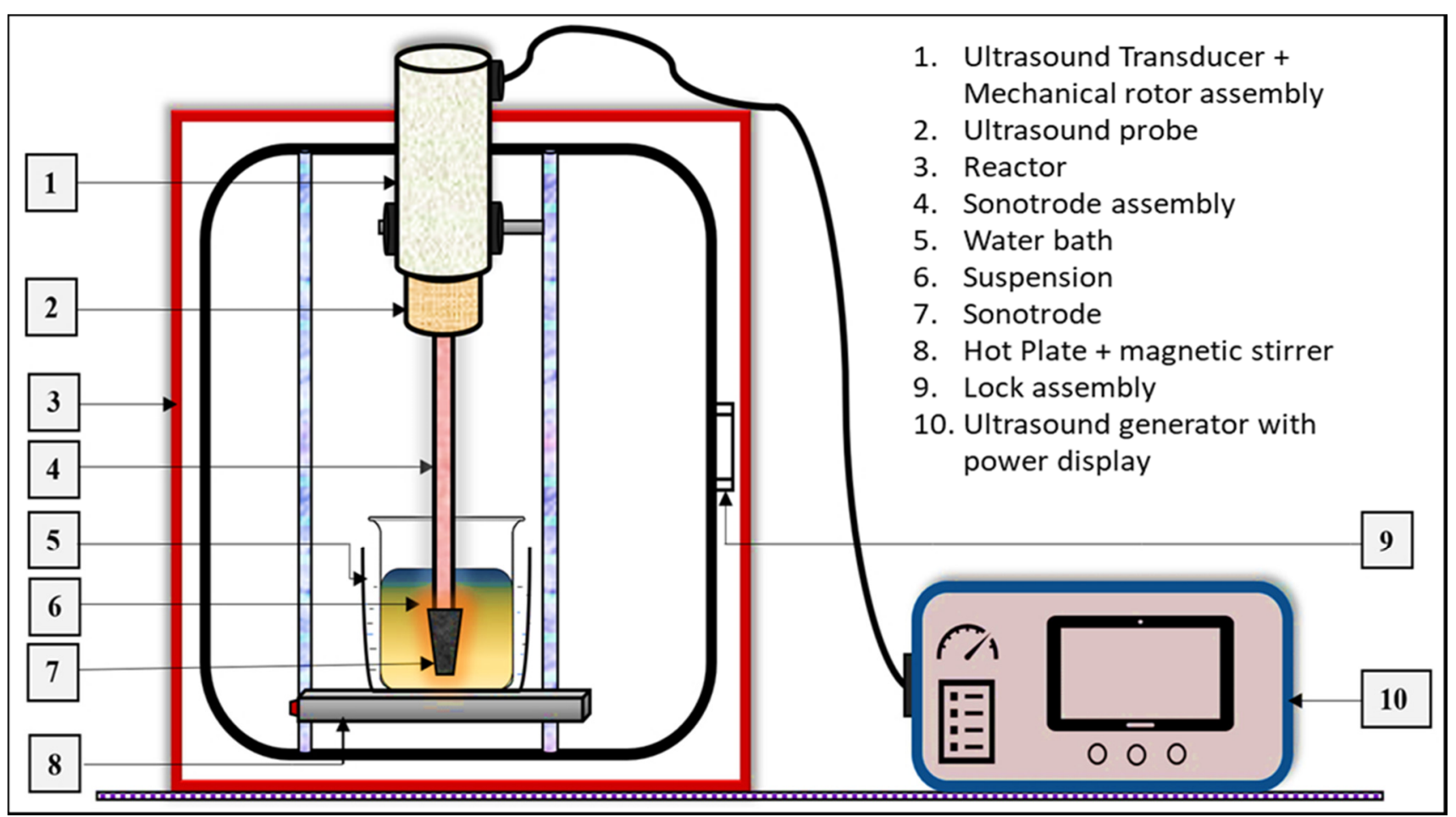

Figure 6. Schematic representation of ultrasound-assisted preparation unit [32].

Table 1. Physicochemical properties of fuel blends.

\begin{tabular}{|c|c|c|c|c|c|c|}
\hline Property & Units & Diesel & SBME25 & $\mathrm{SBME}^{25 \mathrm{SiO}_{2} 25}$ & $\mathrm{SBME}^{25 \mathrm{SiO}_{2} 50}$ & $\mathrm{SBME} 5 \mathrm{SiO}_{2} 75$ \\
\hline Density @25 ㄷ & $\mathrm{kg} / \mathrm{m}^{3}$ & 830 & 876 & 842 & 844 & 845 \\
\hline Heating Value & $\mathrm{kJ} / \mathrm{kg}$ & 43,994 & 40,884 & 41,312 & 42,459 & 42,489 \\
\hline Flash Point & ${ }^{\circ} \mathrm{C}$ & 70 & 86 & 81 & 79 & 78 \\
\hline Fire Point & ${ }^{\circ} \mathrm{C}$ & 76 & 98 & 86 & 85 & 83 \\
\hline Cloud Point & ${ }^{\circ} \mathrm{C}$ & -6 & -2 & -2 & -3 & -3 \\
\hline Pour Point & ${ }^{\circ} \mathrm{C}$ & -10 & -5 & -9 & -7 & -8 \\
\hline Kinematic Viscosity @ $40{ }^{\circ} \mathrm{C}$ & CSt & 2.8 & 4.72 & 5.4 & 5.3 & 5.3 \\
\hline
\end{tabular}

\subsection{Test Setup}

The engine used in the current investigation is a variable compression ratio (VCR), Kirloskar made, single-cylinder diesel engine. All the experiments were carried-out in Apex innovation labs, India. The values were measured using in-built Enginesoft software. The test rig consists of different fuel tanks and a three-way stop cock assisted for the different fuel blends. The engine was operated initially on diesel as baseline fuel. The experiment was conducted under varying load condition from no load to $12 \mathrm{~kg}$ loading with an increment of $3 \mathrm{~kg}$ at the rated speed of $1800 \mathrm{rpm}$. After running a few times, it was switched to biodiesel and its blends and run at the same operating conditions. After completing all the tests, the engine was switched back to diesel fuel and continued running for $15 \mathrm{~min}$ until the biodiesel blends were removed from the injector and fuel line. The engine satisfactorily ran throughout the test at the same operating conditions. Three readings were taken for each fuel blend and the average values were noted and the standard deviation and uncertainty analysis of the study were determined. The engine is coupled to a five-gas analyser and smoke meter. DAQ and Labview software is used as an interface between the computer and the engine sensors (air and fuel flow, temperatures and load measurement sensors). Table 2 shows the specification engine used in the current study. Figure 7 shows the VCR diesel engine. 
Table 2. Engine specifications.

\begin{tabular}{cc}
\hline Parameter & Specification \\
\hline Rated Power & 5 HP@ $1800 \mathrm{rpm}$ \\
Bore & $87.5 \mathrm{~mm}$ \\
Stroke & $110 \mathrm{~mm}$ \\
$232 \mathrm{~mm}$ \\
Connecting Rod Length & 5 to 11 for SI mode and 12 to 21.5 for CI mode \\
Compression Ratio & 4 Stroke, Single Cylinder \\
Type & 15 L with glass fuel metering column \\
Fuel tank & Range 5000 psi, with low noise cable \\
Piezo sensor & RTD, PT100 and thermocouple type K \\
Temperature sensor & Eureka, Engine cooling 40-400 LPH; Calorimeter 25-250 LPH \\
Rotameter & Radix, Type RTD, PT100 and Thermocouple, Type K \\
Temperature sensor & Load cell, strain gauge type, range: 0-50 kg \\
Load sensor & Type eddy current, water-cooled with loading unit \\
Dynamometer & Kübler Germany, Resolution 1 Deg, Speed 5500 RPM with top \\
Crank angle sensor & dead centre (TDC) pulse \\
Piezo pressure transducer & Make: Kistler \\
\hline
\end{tabular}

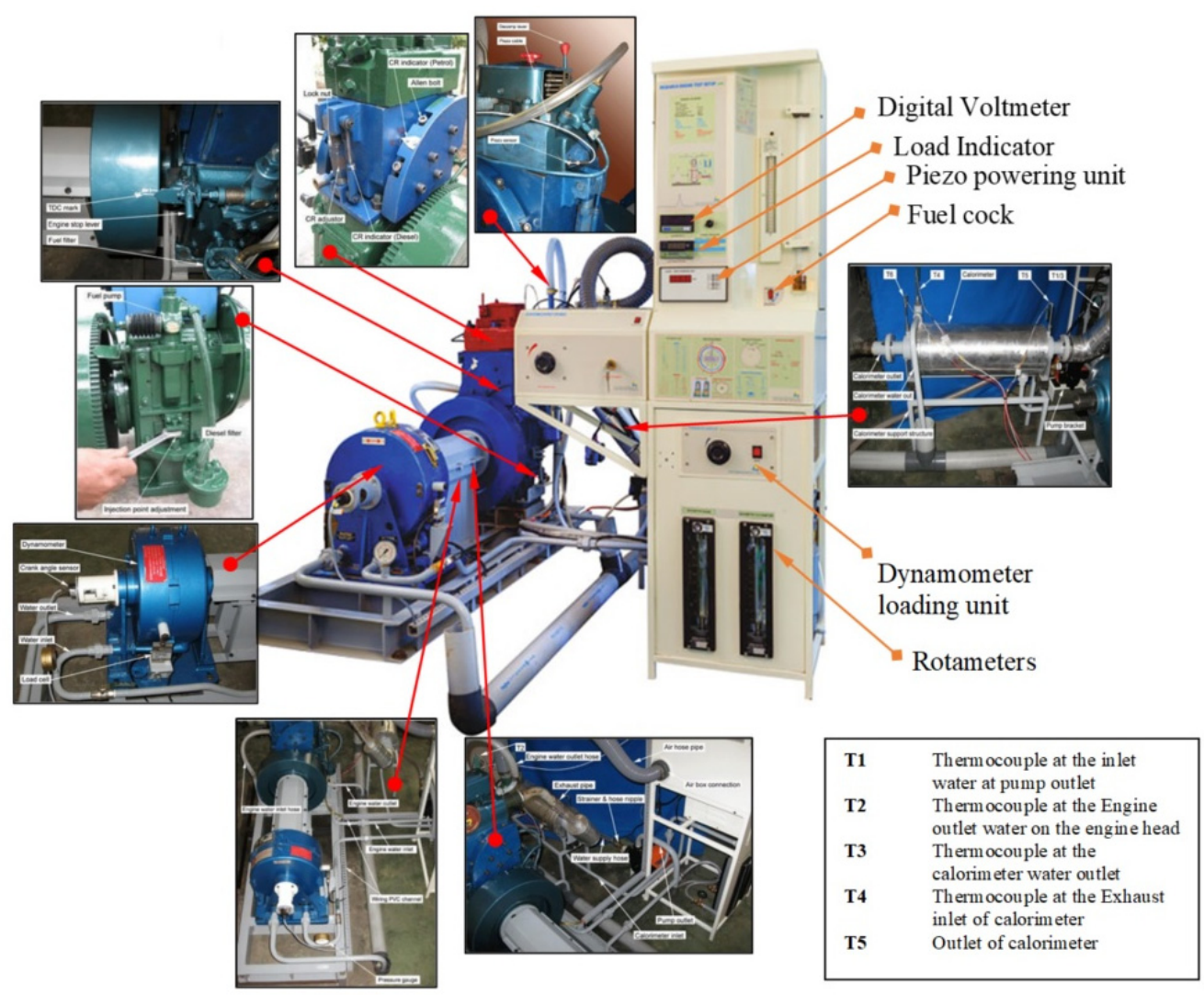

Figure 7. Variable Compression Ratio (VCR) diesel engine.

\subsection{Uncertainty Analysis}

Uncertainty analysis is used to determine the probable errors obtained during the experimentation due to environmental conditions, and some are due to instruments used for the measurement [33-35]. Human errors are also included in these errors. Table 3 shows the percentage of uncertainty and accuracy of various parameters. 
Table 3. Uncertainty and accuracy levels of performance and emission parameters.

\begin{tabular}{ccc}
\hline Parameters & Accuracy ( \pm ) & Uncertainty (\%) \\
\hline BP (kW) & - & \pm 0.4 \\
BTE (\%) & - & \pm 0.4 \\
BSFC (\%) & - & \pm 0.4 \\
CO emission (\%) & $\pm 0.01 \%$ & \pm 0.3 \\
NOx emission (ppm) & $\pm 8 \mathrm{ppm}$ & \pm 0.5 \\
HC emission (ppm) & $\pm 8 \mathrm{ppm}$ & \pm 0.4 \\
Smoke meter (HSU) & \pm 1 & \pm 0.5 \\
\hline
\end{tabular}

\section{Results and Discussion}

\subsection{Effect of Nano-Additive on the Performance Parameters}

\subsubsection{Effect on BTE at Varying Load Condition}

Figure 8 indicates the change in BTE at different loads. The readings were taken for different blends of biodiesel with the addition of nano-additives at various combinations. At every combination, thermal efficiency always increases up to $9 \mathrm{~kg}$ of load. After that, it either stabilises or decreases. Generally, biodiesel's addition reduces the ignition delay, which causes faster combustion resulting in higher peak pressure [10,34]. However, due to the lower heating value of biodiesel owing to its fuel bound oxygen and higher density, the BTE reduction is significant. It has been reported that combustion efficiency is enhanced with the addition of nano-additives as they have the ability to donate oxygen from their lattice structure, thereby catalysing the combustion reaction [21]. They also help in reducing the ignition delay. It was observed that because of the addition of $\mathrm{SiO}_{2}$ nano-additives, enhanced combustion of fuel particles takes place. Hence, blends with nano-additive dosage showed an increase in BTE compared to that of soybean biodiesel blend. At maximum load, the average value of BTE increased by $9.12 \%\left(\mathrm{SBME}_{2} 5 \mathrm{SiO}_{2} 50\right)$ and $7.19 \%$ $\left(\mathrm{SBME}_{25 \mathrm{SiO}} 275\right)$ compared to the SBME25 fuel blend. An increase in BTE of up to 16\% was reported in an earlier report with the addition of MWCNTs into the $20 \%$ jatropha biodiesel blend [36].

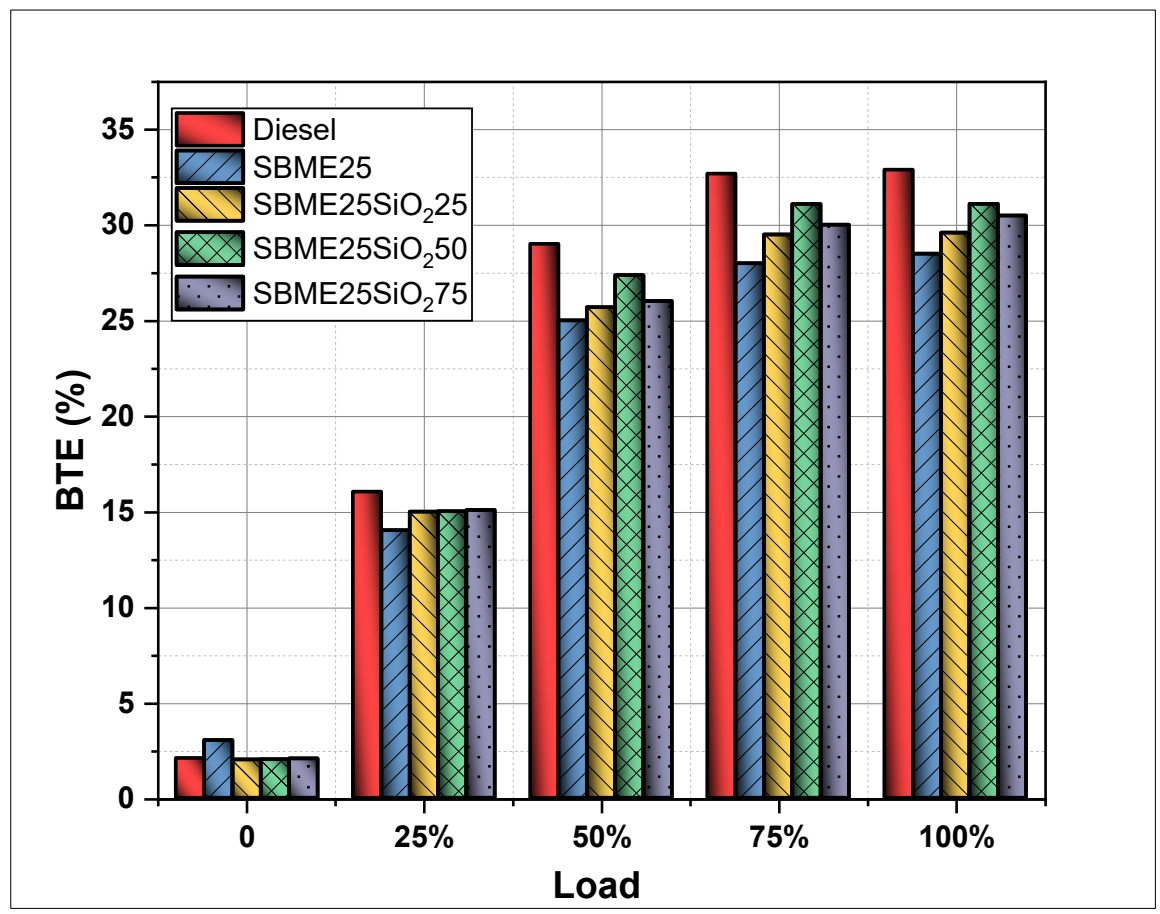

Figure 8. Effect of $\mathrm{SiO}_{2}$ nano-additives on BTE at varying load. 


\subsubsection{Effect on BSFC at Varying Load Condition}

Figure 9 indicates the variation of BSFC concerning load and all combinations of nano fuel. SBME25 biodiesel blend had the highest BSFC and diesel fuel showed the lowest BSFC at all loads. However, the addition of 50 and $75 \mathrm{ppm}$ of $\mathrm{SiO}_{2}$ nano-additive to SBME25 results in lower BSFC than SBME25 biodiesel. As the load increases, the cylinder temperature increases resulting in a reduction in the ignition delay period, which results in a reduction in BSFC $[33,37]$. In addition, at a higher load, lower heat loss is observed. The $\mathrm{SiO}_{2}$ nano-additives acts as a catalyst because of their higher reactive surface area during combustion $[21,33]$. This enhances the combustion after a droplet injected inside the combustion chamber, resulting in lower BSFC compared to SBME25. Hence, a reduction in $\mathrm{BSFC}$ of about $9.88 \%, 5.81 \%$ for $\mathrm{SBME}_{2} 5 \mathrm{SiO}_{2} 50$ and $\mathrm{SBME}_{2} 5 \mathrm{SiO}_{2} 75$ were observed compared to SBME25, respectively. El-Seesy et al. [36] reported a reduction in BSFC of up to $15 \%$ with the addition of MWCNTs into the $20 \%$ jatropha biodiesel blend.

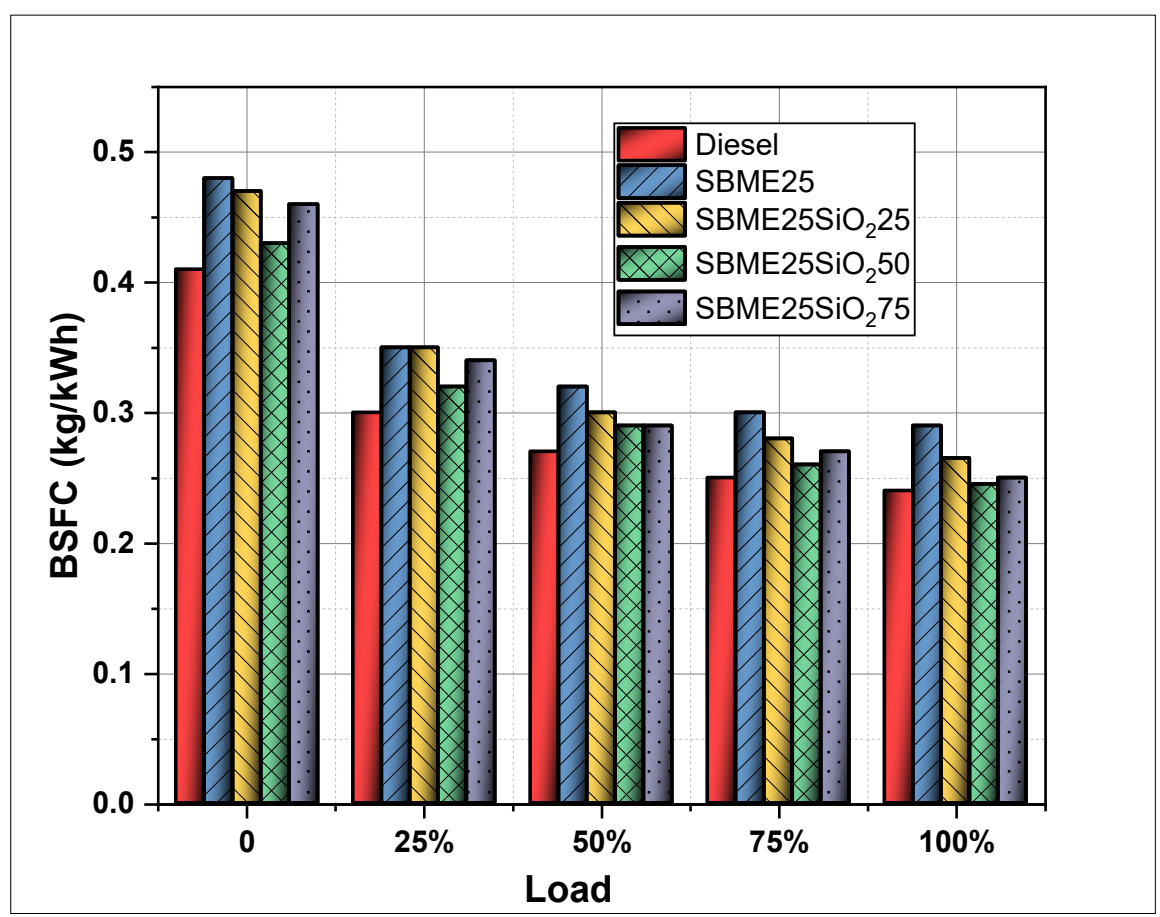

Figure 9. Effect of $\mathrm{SiO}_{2}$ nano-additives on Brake Specific Fuel Consumption (BSFC) at varying loads.

\subsection{Effect of Nano-Additive on the Engine Emission Parameters}

3.2.1. Effect on CO Emission at Varying Load Condition

$\mathrm{CO}$ is formed during combustion whenever the air-fuel mixture is burned with an insufficient air supply with low flame temperature [35]. It can be observed from Figure 10 that with the increase in load, the $\mathrm{CO}$ emission was increased. With the increase in load gradually, the volumetric efficiency increases. However, due to insufficient time for combustion, incomplete combustion occurs, resulting in the formation of $\mathrm{CO}$. As mentioned previously, the addition of biodiesel results in higher cylinder temperature and higher combustion pressure improving the combustion efficiency. Hence, $\mathrm{CO}$ emissions were found to be lower for biodiesel blends. As mentioned previously, oxygenated nanoadditives provide oxygen molecules in a chain reaction, causing complete combustion to reduce $\mathrm{CO}$ compared to baseline fuel (SBME25) [21,38]. SBME25SiO 275 fuel gives the lowest $\mathrm{CO}$ emission compared to all other blends. The $\mathrm{CO}$ emissions were decreased by

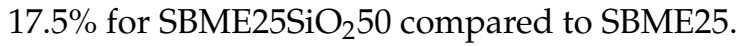




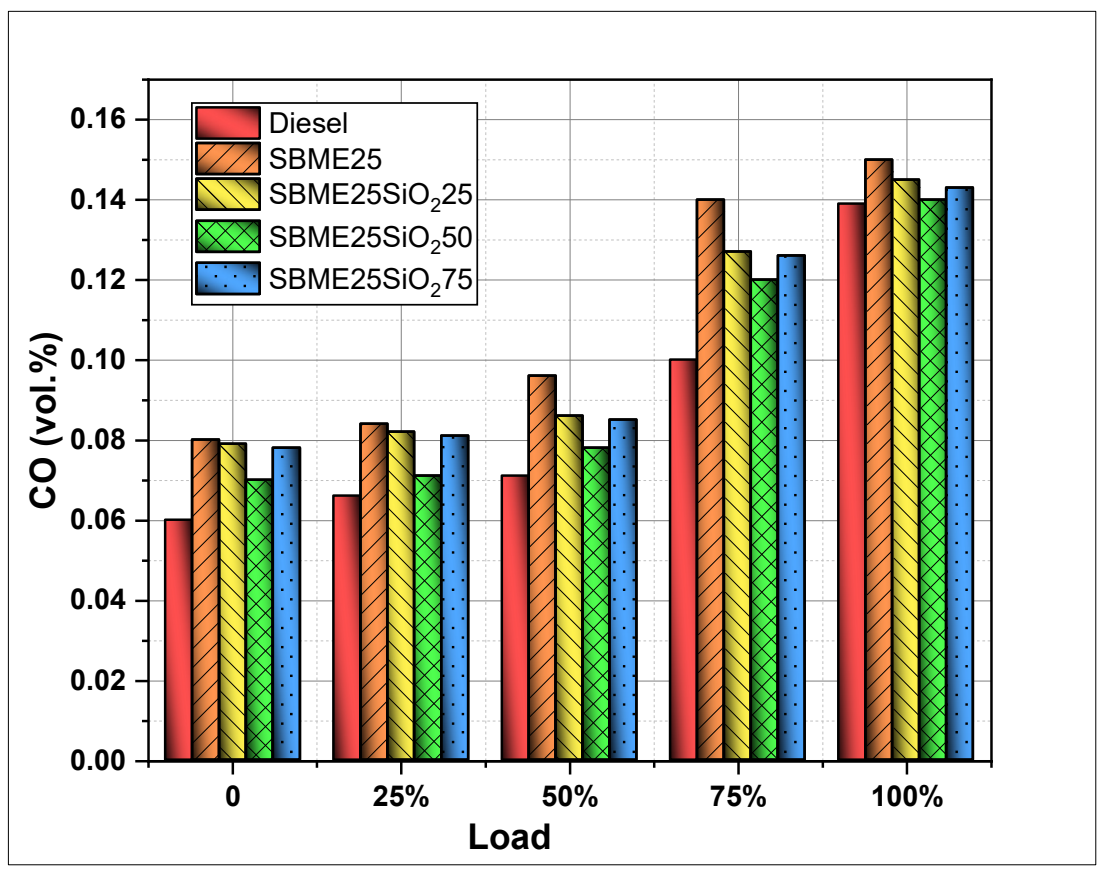

Figure 10. Effect of $\mathrm{SiO}_{2}$ nano-additives on $\mathrm{CO}$ emission at varying loads.

\subsubsection{Effect on HC Emission at Varying Load Condition}

HC emissions rely on fuel density, fuel flow properties, fuel spray patterns and engine operating conditions [5,39]. As mentioned previously, the addition of biodiesel results in higher cylinder temperature and higher combustion pressure improving the combustion efficiency. This results in a reduction in HC emission compared to baseline diesel fuel. $\mathrm{HC}$ emissions were reduced by $27.5 \%$ and $20.56 \%$ for $\mathrm{SBME}_{2} 5 \mathrm{SiO}_{2} 50$ and $\mathrm{SBME}_{2} 5 \mathrm{SiO}_{2} 75$, respectively, compared to SBME25 shown in Figure 11. SBME25 blend shows the highest $\mathrm{HC}$ emissions in the biodiesel blends with or without additives. This can be attributed to its high density, as well as viscosity, which in turn results in poor fuel atomisation.

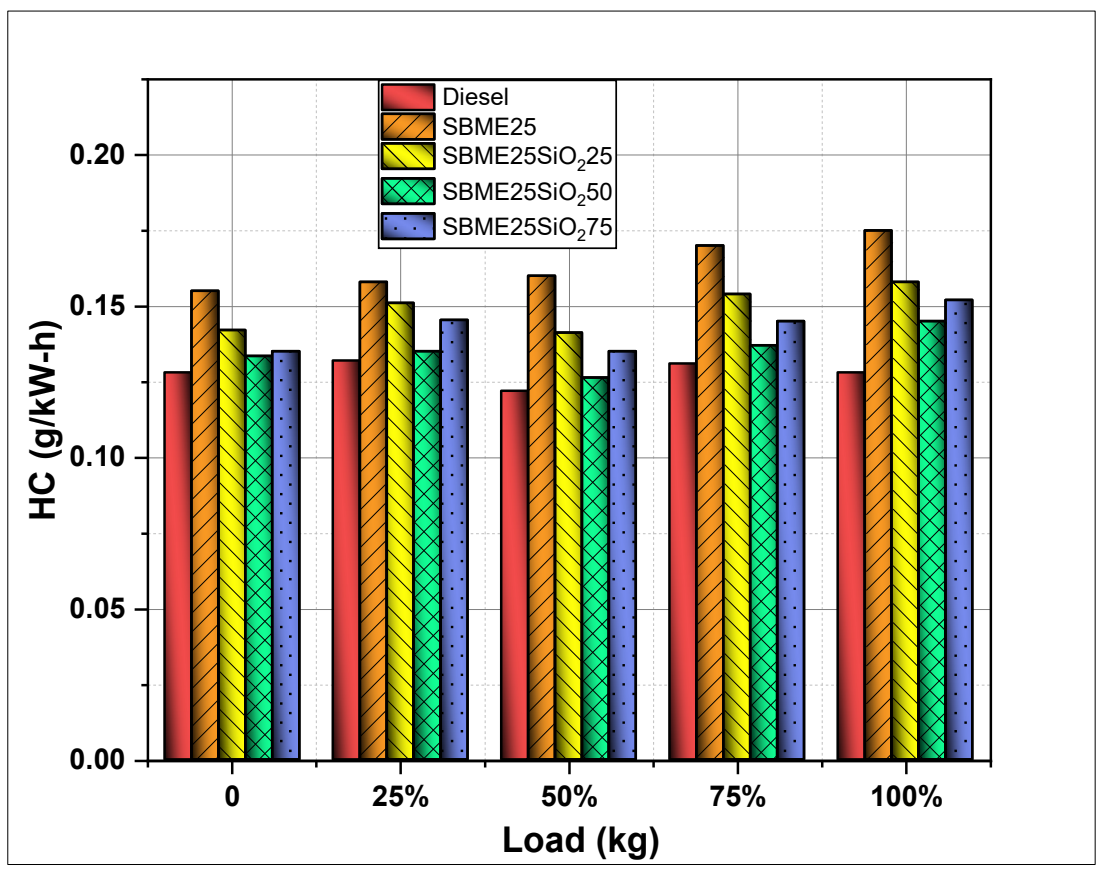

Figure 11. Effect of $\mathrm{SiO}_{2}$ nano-additives on hydrocarbon (HC) at varying load. 


\subsubsection{Effect on NOx Emission at Varying Load Condition}

Figure 12 explains the NOx emissions for various biofuel blends. It was observed from the plots that NOx emission increases with an increase in load. NOx emissions are generated at a very high temperature and pressure [40]. The addition of oxygenated fuel, such as biodiesel, enhances combustion, thereby increasing the NOx emission. With the addition of nano-additives, a faster premixed-combustion occurs, which produces higher combustion temperature inside the chamber and the subsequent higher NOx emission than baseline fuel [21]. All nano fuel blends show an increase in NOx emissions compared to only biodiesel blend due to this elevated in-cylinder temperature and pressure. The NOx emissions were increased by $7.6 \%$ and $10.25 \%$ for $\mathrm{SBME}_{2} 5 \mathrm{SiO}_{2} 50$ and $\mathrm{SBME}_{2} 5 \mathrm{SiO}_{2} 75$, respectively, compared to SBME25.

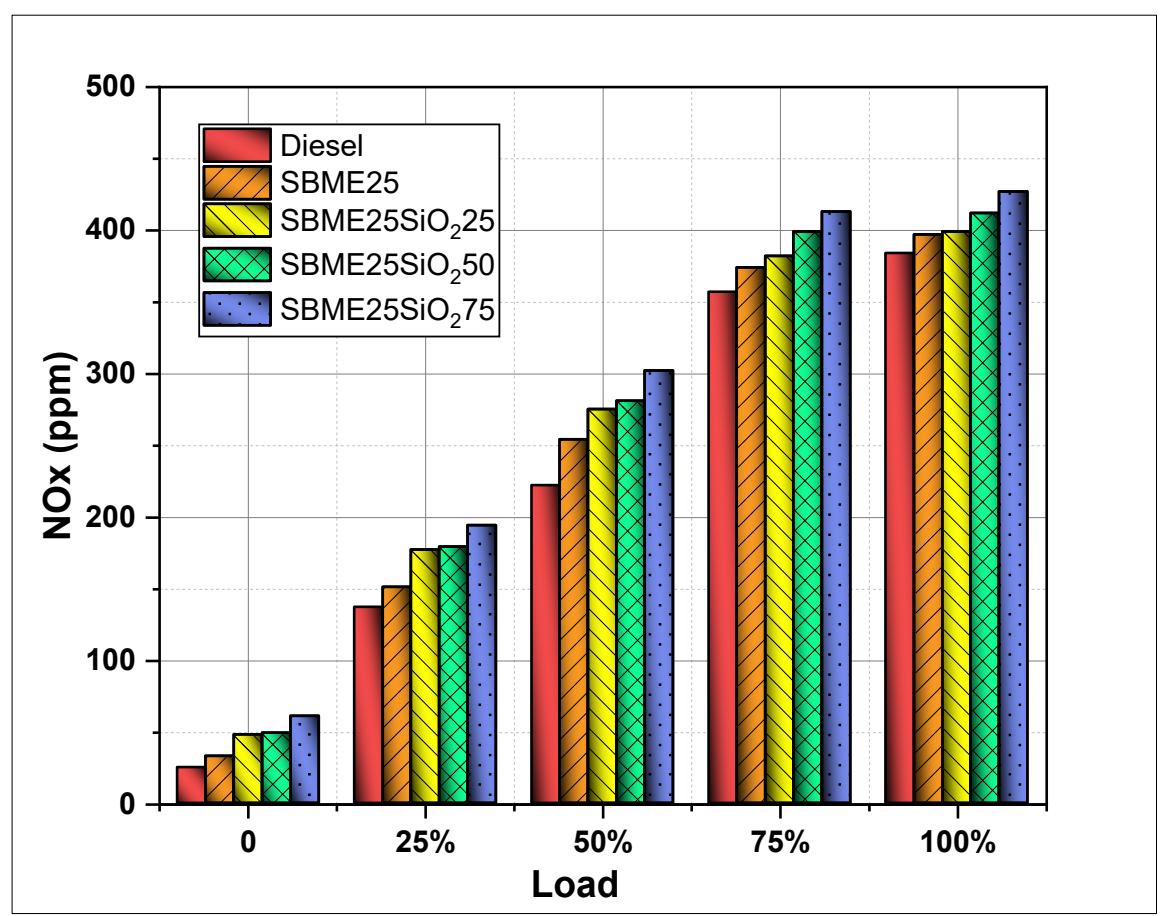

Figure 12. Effect of $\mathrm{SiO}_{2}$ nano-additives on $\mathrm{NOx}$ at varying load.

\subsubsection{Effect on Smoke Emission at Varying Load Condition}

Figure 13 shows the production of smoke with the variation in engine load. It was observed that smoke is highly dependent on the engine load. Smoke opacity increases with an increase in the engine loads [41,42]. Other input parameters have less affecting on smoke. The diesel fuel combustion produced the maximum smoke opacity, and the addition of biodiesel results in enhanced combustion and thereby higher combustion temperature inside the chamber. The higher temperature enhances the combustion resulting in less smoke emission compared to diesel fuel. On the contrary, the addition of silica nanoadditives with SBME25 produces better micro-explosion of blend leading to less smoke opacity. As shown in Figure 13, the smoke emission for $\mathrm{SBME}_{2} 5 \mathrm{SiO}_{2} 50$ and $\mathrm{SBME} 25 \mathrm{SiO}_{2} 75$ was reduced by $23.54 \%$ and $10.16 \%$, respectively, compared to that of SBME25. The maximum surface area of the $\mathrm{SBME}_{2} 5 \mathrm{SiO}_{2} 50$ nano-additives improves the combustion phenomenon, and hence, the fuel combustion. 


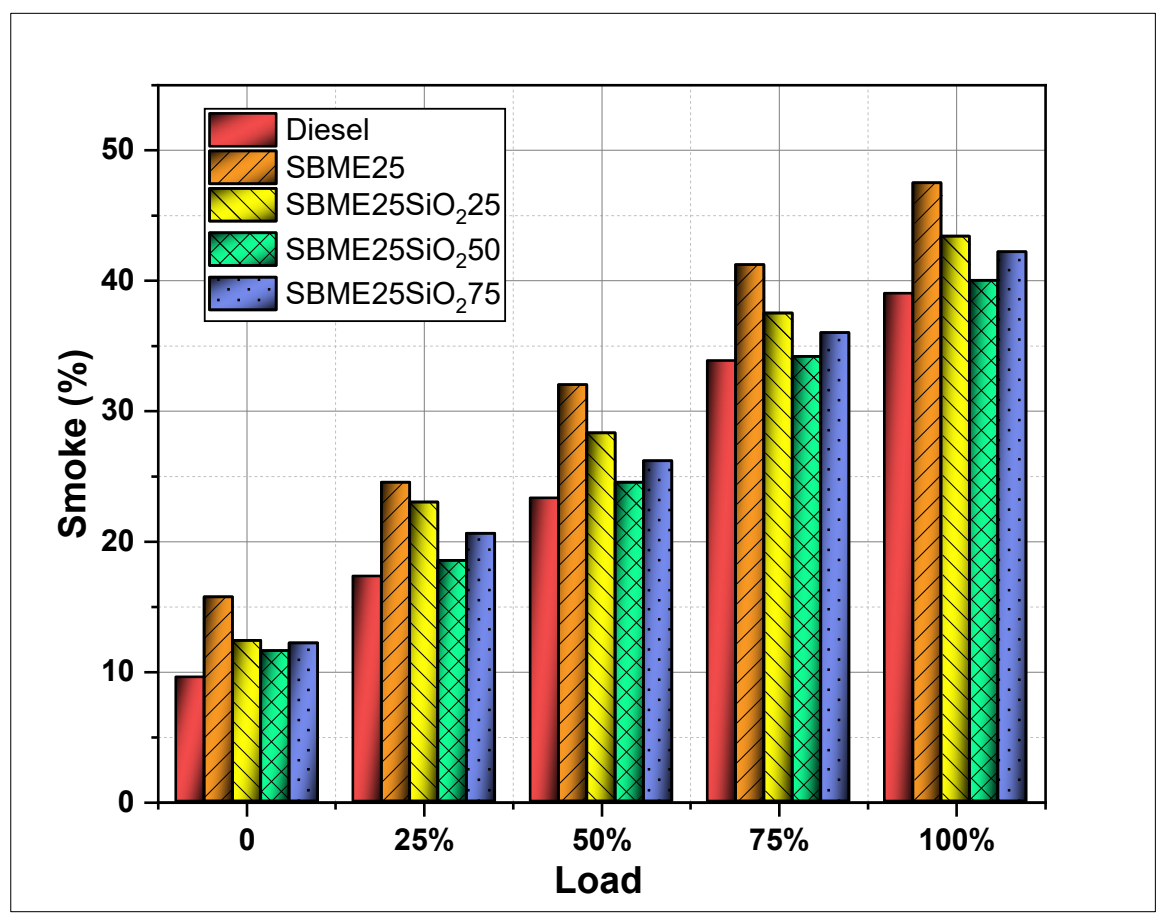

Figure 13. Effect of $\mathrm{SiO}_{2}$ nano-additive on smoke at varying loads.

\section{Conclusions}

The present study is focused on the effect of $\mathrm{SiO}_{2}$ nano-additive on the performance and emission characteristics of soybean biodiesel (SBME25) fuelled diesel engine. The nano-additives in biodiesel act as a combustion catalyst which enhance the combustion phenomenon, ensuring complete combustion. This is attributed to the increase in net heat generated inside the combustion chamber that enhances the BTE with the reduction in BSFC. Furthermore, the addition of these nanoparticle reduces emissions like $\mathrm{CO}_{2}, \mathrm{HC}$ and smoke, except NOx. The NOx increases with an increase in combustion chamber temperature due to complete combustion. The addition of $\mathrm{SiO}_{2}$ nano-additives in the soybean biodiesel blend increased the BTE by 3.48-9.12\% and decreased the BSFC by $5.81-11.58 \%$, respectively. The CO, HC and smoke emissions for nano-additive added blends were decreased by $1.9-17.5 \%, 20.56-27.5 \%$ and $10.16-23.54 \%$ compared to SBME25 fuel blends. However, the NOx slightly increases for all the nanofuel blends due to the rise in in-cylinder temperature and the presence of a large number of oxygen molecules due to the utilisation of oxides of silicon and the presence of oxygen in biodiesel. As a recommendation, the NOx formation can be controlled by using exhaust gas recirculation.

Author Contributions: Conceptualisation, R.S.G. and M.E.M.S.; methodology, R.S.G. and M.E.M.S.; software, M.E.M.S. and I.M.R.F.; validation, I.M.R.F., V.D.W., S.B. and M.E.M.S.; formal analysis, H.F. and T.M.Y.K.; investigation M.A.M. and R.K.; resources, R.S.G., A.M.K. and M.E.M.S.; data curation, N.-N.N.-G. and M.E.M.S.; writing—original draft preparation, R.S.G., M.E.M.S. and I.M.R.F.; writingreview and editing, M.E.M.S., M.S., H.F., T.M.Y.K., M.A.M. and I.M.R.F.; supervision, A.M.K.; project administration, M.E.M.S. and I.M.R.F.; funding acquisition, M.S., I.M.R.F. and T.M.Y.K. All authors have read and agreed to the published version of the manuscript.

Funding: Deanship of Scientific Research at King Khalid University, Grant Number R.G.P. 1/251/42.

Acknowledgments: The authors extend their appreciation to the Deanship of Scientific Research at King Khalid University for funding this work through Grant Number R.G.P. 1/251/42. The authors would also like to acknowledge the Research Development Fund of the School of Information, Systems and Modelling, Faculty of Engineering and Information Technology, University of Technology, Sydney, Australia.

Conflicts of Interest: The authors declare no conflict of interest. 


\begin{tabular}{|c|c|}
\hline Nomenclature & \\
\hline NPs & Nanoparticles \\
\hline VCR & Variable Compression Ratio \\
\hline $\mathrm{CO}_{2}$ & Carbon dioxide \\
\hline $\mathrm{NO}_{X}$ & Oxides of nitrogen \\
\hline $\mathrm{HC}$ & Hydrocarbon \\
\hline BTE & Brake thermal efficiency \\
\hline $\mathrm{nm}$ & Nanometre \\
\hline $\mathrm{g} / \mathrm{kWh}$ & Grams per kilowatt hour \\
\hline ATDC & After top dead centre \\
\hline Sr@ZnO & Strontium coated Zinc oxide \\
\hline SBME25 & $\begin{array}{l}25 \% \text { Soybean methyl ester } \\
\text { blended with diesel }\end{array}$ \\
\hline $\mathrm{SBME} 5 \mathrm{SiO}_{2} 50$ & SBME25 and 50 ppm $\mathrm{SiO}_{2}$ NPs \\
\hline XRD & X-ray diffraction \\
\hline ULSD & Ultra-low sulphur diesel \\
\hline SEM & Scanning electron microscopy \\
\hline $\mathrm{SiO}_{2}$ & Silicon dioxide \\
\hline SDS & Sodium dodecyl sulphate \\
\hline $\mathrm{CO}$ & Carbon monoxide \\
\hline PM & Particulate matter \\
\hline${ }^{\circ} \mathrm{CA}$ & Crank angle (degrees) \\
\hline BSFC & Brake specific fuel consumption \\
\hline ppm & Parts per million \\
\hline MWCNT & Multi-walled Carbon nanotubes \\
\hline BTDC & Before top dead centre \\
\hline SBME & Soybean methyl ester \\
\hline $\mathrm{SBME} 5 \mathrm{SiO}_{2} 25$ & SBME25 and 25 ppm $\mathrm{SiO}_{2} \mathrm{NPs}$ \\
\hline $\mathrm{SBME} 25 \mathrm{SiO}_{2} 75$ & SBME25 and 75 ppm $\mathrm{SiO}_{2} \mathrm{NPs}$ \\
\hline DAQ & Data Acquisition \\
\hline GO & Graphene oxide \\
\hline EDS & Energy Dispersive Spectroscopy \\
\hline
\end{tabular}

\section{References}

1. Soudagar, M.E.M.; Nik-Ghazali, N.-N.; Kalam, M.A.; Badruddin, I.; Banapurmath, N.; Akram, N. The effect of nano-additives in diesel-biodiesel fuel blends: A comprehensive review on stability, engine performance and emission characteristics. Energy Convers. Manag. 2018, 178, 146-177. [CrossRef]

2. Soudagar, M.E.M.; Banapurmath, N.; Afzal, A.; Hossain, N.; Abbas, M.M.; Haniffa, M.A.C.M.; Naik, B.; Ahmed, W.; Nizamuddin, S.; Mubarak, N. Study of diesel engine characteristics by adding nano-sized zinc oxide and diethyl ether additives in Mahua biodiesel-diesel fuel blend. Sci. Rep. 2020, 10, 1-17. [CrossRef] [PubMed]

3. Soudagar, M.E.M.; Nik-Ghazali, N.-N.; Kalam, M.; Badruddin, I.A.; Banapurmath, N.; Ali, M.A.B.; Kamangar, S.; Cho, H.M.; Akram, N. An investigation on the influence of aluminium oxide nano-additive and honge oil methyl ester on engine performance, combustion and emission characteristics. Renew. Energy 2020, 146, 2291-2307. [CrossRef]

4. Shahir, S.; Masjuki, H.; Kalam, M.; Imran, A.; Fattah, I.R.; Sanjid, A. Feasibility of diesel-biodiesel-ethanol/bioethanol blend as existing CI engine fuel: An assessment of properties, material compatibility, safety and combustion. Renew. Sustain. Energy Rev. 2014, 32, 379-395. [CrossRef]

5. Imtenan, S.; Varman, M.; Masjuki, H.; Kalam, M.; Sajjad, H.; Arbab, M.; Fattah, I.R. Impact of low temperature combustion attaining strategies on diesel engine emissions for diesel and biodiesels: A review. Energy Convers. Manag. 2014, 80, 329-356. [CrossRef]

6. Fattah, I.R.; Masjuki, H.; Kalam, M.; Hazrat, M.; Masum, B.; Imtenan, S.; Ashraful, A. Effect of antioxidants on oxidation stability of biodiesel derived from vegetable and animal based feedstocks. Renew. Sustain. Energy Rev. 2014, 30, 356-370. [CrossRef]

7. Khan, H.; Soudagar, M.E.M.; Kumar, R.H.; Safaei, M.R.; Farooq, M.; Khidmatgar, A.; Banapurmath, N.R.; Farade, R.A.; Abbas, M.M.; Afzal, A. Effect of Nano-Graphene Oxide and n-Butanol Fuel Additives Blended with Diesel-Nigella sativa Biodiesel Fuel Emulsion on Diesel Engine Characteristics. Symmetry 2020, 12, 961. [CrossRef]

8. Rahman, S.M.A.; Fattah, I.M.R.; Maitra, S.; Mahlia, T.M.I. A ranking scheme for biodiesel underpinned by critical physicochemical properties. Energy Convers. Manag. 2021, 229, 113742. [CrossRef] 
9. Mofijur, M.; Masjuki, H.H.; Kalam, M.A.; Atabani, A.E.; Rizwanul Fattah, I.M.; Mobarak, H.M. Comparative evaluation of performance and emission characteristics of Moringa oleifera and Palm oil based biodiesel in a diesel engine. Ind. Crops Prod. 2014, 53, 78-84. [CrossRef]

10. Fattah, I.M.R.; Masjuki, H.H.; Kalam, M.A.; Mofijur, M.; Abedin, M.J. Effect of antioxidant on the performance and emission characteristics of a diesel engine fueled with palm biodiesel blends. Energy Convers. Manag. 2014, 79, 265-272. [CrossRef]

11. Gavhane, R.S.; Kate, A.M.; Pawar, A.; Soudagar, M.E.M.; Fayaz, H. Effect of Soybean biodiesel and Copper coated Zinc oxide Nanoparticles on Enhancement of Diesel Engine Characteristics. Energy Sources Part A Recovery Util. Environ. Eff. 2020, 1-19. [CrossRef]

12. Palash, S.M.; Masjuki, H.H.; Kalam, M.A.; Atabani, A.E.; Rizwanul Fattah, I.M.; Sanjid, A. Biodiesel production, characterisation, diesel engine performance, and emission characteristics of methyl esters from Aphanamixis polystachya oil of Bangladesh. Energy Convers. Manag. 2015, 91, 149-157. [CrossRef]

13. Özener, O.; Yüksek, L.; Ergenç, A.T.; Özkan, M. Effects of soybean biodiesel on a DI diesel engine performance, emission and combustion characteristics. Fuel 2014, 115, 875-883. [CrossRef]

14. Seraç, M.R.; Aydın, S.; Yılmaz, A.; Şevik, S. Evaluation of comparative combustion, performance, and emission of soybean-based alternative biodiesel fuel blends in a CI engine. Renew. Energy 2020, 148, 1065-1073. [CrossRef]

15. Fayaz, H.; Mujtaba, M.A.; Soudagar, M.E.M.; Razzaq, L.; Nawaz, S.; Nawaz, M.A.; Farooq, M.; Afzal, A.; Ahmed, W.; Khan, T.M.Y.; et al. Collective effect of ternary nano fuel blends on the diesel engine performance and emissions characteristics. Fuel 2021, 293, 120420. [CrossRef]

16. Ong, H.C.; Tiong, Y.W.; Goh, B.H.H.; Gan, Y.Y.; Mofijur, M.; Fattah, I.M.R.; Chong, C.T.; Alam, M.A.; Lee, H.V.; Silitonga, A.S.; et al. Recent advances in biodiesel production from agricultural products and microalgae using ionic liquids: Opportunities and challenges. Energy Convers. Manag. 2020, 113647. [CrossRef]

17. Razzaq, L.; Mujtaba, M.A.; Soudagar, M.E.M.; Ahmed, W.; Fayaz, H.; Bashir, S.; Fattah, I.M.R.; Ong, H.C.; Shahapurkar, K.; Afzal, A.; et al. Engine performance and emission characteristics of palm biodiesel blends with graphene oxide nanoplatelets and dimethyl carbonate additives. J. Environ. Manag. 2021, 282, 111917. [CrossRef] [PubMed]

18. Hussain, F.; Soudagar, M.E.M.; Afzal, A.; Mujtaba, M.; Fattah, I.M.R.; Naik, B.; Mulla, M.H.; Badruddin, I.A.; Khan, T.M.Y.; Raju, V.D.; et al. Enhancement in Combustion, Performance, and Emission Characteristics of a Diesel Engine Fueled with Ce-ZnO Nanoparticle Additive Added to Soybean Biodiesel Blends. Energies 2020, 13, 4578. [CrossRef]

19. Mujtaba, M.; Kalam, M.; Masjuki, H.; Gul, M.; Soudagar, M.E.M.; Ong, H.C.; Ahmed, W.; Atabani, A.; Razzaq, L.; Yusoff, M. Comparative study of nanoparticles and alcoholic fuel additives-biodiesel-diesel blend for performance and emission improvements. Fuel 2020, 279, 118434. [CrossRef]

20. Gavhane, R.S.; Kate, A.M.; Pawar, A.; Safaei, M.R.; Soudagar, M.E.M.; Abbas, M.M.; Ali, H.M.; Banapurmath, N.R.; Goodarzi, M.; Badruddin, I.A.; et al. Effect of Zinc Oxide Nano-Additives and Soybean Biodiesel at Varying Loads and Compression Ratios on VCR Diesel Engine Characteristics. Symmetry 2020, 12, 1042. [CrossRef]

21. Najafi, G. Diesel engine combustion characteristics using nanoparticles in biodiesel-diesel blends. Fuel 2018, 212, 668-678. [CrossRef]

22. Mujtaba, M.; Masjuki, H.; Kalam, M.; Noor, F.; Farooq, M.; Ong, H.C.; Gul, M.; Soudagar, M.E.M.; Bashir, S.; Rizwanul Fattah, I. Effect of Additivized Biodiesel Blends on Diesel Engine Performance, Emission, Tribological Characteristics, and Lubricant Tribology. Energies 2020, 13, 3375. [CrossRef]

23. Ghanbari, M.; Najafi, G.; Ghobadian, B.; Yusaf, T.; Carlucci, A.; Kiani, M.K.D. Performance and emission characteristics of a CI engine using nano particles additives in biodiesel-diesel blends and modeling with GP approach. Fuel 2017, 202, 699-716. [CrossRef]

24. Adzmi, M.A.; Abdullah, A.; Abdullah, Z.; Mrwan, A.G. Effect of $\mathrm{Al}_{2} \mathrm{O}_{3}$ and $\mathrm{SiO}_{2}$ Metal Oxide Nanoparticles Blended with POME on Combustion, Performance and Emissions Characteristics of a Diesel Engine. Int. J. Automot. Mech. Eng. 2019, 16, 6859-6873. [CrossRef]

25. Saravankumar, P.T.; Suresh, V.; Vijayan, V.; Godwin Antony, A. Ecological effect of corn oil biofuel with SiO2 nano-additives. Energy Sources Part A Recovery Util. Environ. Eff. 2019, 41, 2845-2852. [CrossRef]

26. Özgür, T.; Özcanli, M.; Aydin, K. Investigation of Nanoparticle Additives to Biodiesel for Improvement of the Performance and Exhaust Emissions in a Compression Ignition Engine. Int. J. Green Energy 2015, 12, 51-56. [CrossRef]

27. Habibullah, M.; Masjuki, H.H.; Kalam, M.A.; Rizwanul Fattah, I.M.; Ashraful, A.M.; Mobarak, H.M. Biodiesel production and performance evaluation of coconut, palm and their combined blend with diesel in a single-cylinder diesel engine. Energy Convers. Manag. 2014, 87, 250-257. [CrossRef]

28. Her, Y.-S.; Lee, S.-H.; Matijević, E. Continuous precipitation of monodispersed colloidal particles. II. $\mathrm{SiO} 2, \mathrm{Al}(\mathrm{OH}) 3$, and BaTiO3. J. Mater. Res. 1996, 11, 156-161. [CrossRef]

29. Bajpai, N.; Tiwari, A.; Khan, S.; Kher, R.; Bramhe, N.; Dhoble, S. Effects of rare earth ions (Tb, Ce, Eu, Dy) on the thermoluminescence characteristics of sol-gel derived and $\gamma$-irradiated SiO2 nanoparticles. Luminescence 2014, 29, 669-673. [CrossRef]

30. Tabatabaei, S.; Shukohfar, A.; Aghababazadeh, R.; Mirhabibi, A. Experimental study of the synthesis and characterisation of silica nanoparticles via the sol-gel method. In Proceedings of Journal of Physics: Conference Series; IOP Publishing Ltd.: Bristol, UK, 2006; p. 371.

31. Musić, S.; Filipović-Vinceković, N.; Sekovanić, L. Precipitation of amorphous $\mathrm{SiO} 2$ particles and their properties. Braz. J. Chem. Eng. 2011, 28, 89-94. [CrossRef] 
32. Soudagar, M.E.M.; Mujtaba, M.; Safaei, M.R.; Afzal, A.; Ahmed, W.; Banapurmath, N.; Hossain, N.; Bashir, S.; Badruddin, I.A.; Goodarzi, M. Effect of Sr@ ZnO nanoparticles and Ricinus communis biodiesel-diesel fuel blends on modified CRDI diesel engine characteristics. Energy 2020, 215, 119094. [CrossRef]

33. Hoseini, S.; Najafi, G.; Ghobadian, B.; Ebadi, M.; Mamat, R.; Yusaf, T. Performance and emission characteristics of a CI engine using graphene oxide (GO) nano-particles additives in biodiesel-diesel blends. Renew. Energy 2020, 145, 458-465. [CrossRef]

34. Fattah, I.M.R.; Masjuki, H.H.; Kalam, M.A.; Wakil, M.A.; Ashraful, A.M.; Shahir, S.A. Experimental investigation of performance and regulated emissions of a diesel engine with Calophyllum inophyllum biodiesel blends accompanied by oxidation inhibitors. Energy Convers. Manag. 2014, 83, 232-240. [CrossRef]

35. Fattah, I.M.R.; Masjuki, H.H.; Kalam, M.A.; Wakil, M.A.; Rashedul, H.K.; Abedin, M.J. Performance and emission characteristics of a CI engine fueled with Cocos nucifera and Jatropha curcas B20 blends accompanying antioxidants. Ind. Crops Prod. 2014, 57, 132-140. [CrossRef]

36. El-Seesy, A.I.; Abdel-Rahman, A.K.; Bady, M.; Ookawara, S. Performance, combustion, and emission characteristics of a diesel engine fueled by biodiesel-diesel mixtures with multi-walled carbon nanotubes additives. Energy Convers. Manag. 2017, 135, 373-393. [CrossRef]

37. Basha, J.S. An Experimental Analysis of a Diesel Engine Using Alumina Nanoparticles Blended DIESEL fuel; 0148-7191; SAE Technical Paper; SAE International: Warrendale, PA, USA, 2014.

38. Harari, P.; Banapurmath, N.; Yaliwal, V.; Khan, T.Y.; Soudagar, M.E.M.; Sajjan, A. Experimental studies on performance and emission characteristics of reactivity controlled compression ignition (RCCI) engine operated with gasoline and Thevetia Peruviana biodiesel. Renew. Energy 2020, 160, 865-875. [CrossRef]

39. Akkoli, K.M.; Banapurmath, N.R.; Shivashimpi, M.M.; Soudagar, M.E.M.; Badruddin, I.A.; Alazwari, M.A.; Yaliwal, V.S.; Mujtaba, M.A.; Akram, N.; Goodarzi, M.; et al. Effect of injection parameters and producer gas derived from redgram stalk on the performance and emission characteristics of a diesel engine. Alex. Eng. J. 2021, 60, 3133-3142. [CrossRef]

40. Ming, C.; Rizwanul Fattah, I.M.; Chan, Q.N.; Pham, P.X.; Medwell, P.R.; Kook, S.; Yeoh, G.H.; Hawkes, E.R.; Masri, A.R. Combustion scharacterisation of waste cooking oil and canola oil based biodiesels under simulated engine conditions. Fuel 2018, 224, 167-177. [CrossRef]

41. Sayin, C.; Ilhan, M.; Canakci, M.; Gumus, M. Effect of injection timing on the exhaust emissions of a diesel engine using diesel-methanol blends. Renew. Energy 2009, 34, 1261-1269. [CrossRef]

42. Soudagar, M.; Afzal, A.; Kareemullah, M. Waste coconut oil methyl ester with and without additives as an alternative fuel in diesel engine at two different injection pressures. Energy Sources Part A Recovery Util. Environ. Eff. 2020. [CrossRef] 